\title{
The Improvement of Oxidation Resistance of a Re-Based Diffusion Barrier/Ni-Al Coating on the Single-Crystal Ni-Based TMS-82+ Superalloy
}

\author{
Y. Wu $\cdot$ Y. M. Wang $\cdot$ G. M. Song $\cdot$ X. W. Li
}

Received: 3 March 2011/Revised: 8 June 2011/Published online: 21 June 2011

(C) Springer Science+Business Media, LLC 2011

\begin{abstract}
Oxidation behavior of a Re-based diffusion barrier/ $\mathrm{Ni}-\mathrm{Al}$ coated singlecrystal (SC) Ni-based TMS-82+ superalloy was studied to compare with those of the base and $\mathrm{Ni}-\mathrm{Al}$ coated superalloys under cyclic air at $1150{ }^{\circ} \mathrm{C}$ for $200 \mathrm{~h}$. The base superalloy showed a negative mass gain due to extensive oxide spallation, and the $\mathrm{Ni}-\mathrm{Al}$ coated superalloy without the diffusion barrier started to spall slightly after about $90 \mathrm{~h}$. The oxidation resistance of the $\mathrm{Ni}-\mathrm{Al}$ coated superalloy with the Re-based diffusion barrier was greatly improved due to the formation of a dense $\alpha-\mathrm{Al}_{2} \mathrm{O}_{3}$ layer in the scale. The Re-based alloy was an effective diffusion barrier layer against inward diffusion of $\mathrm{Al}$ and outward diffusion of alloying elements in the alloy substrate due to the reduced thickness of interdiffusion zone with small amount of detrimental precipitates and higher content of $\mathrm{Al}$ in the $\mathrm{Ni}-\mathrm{Al}$ coating that supplied enough $\mathrm{Al}$ for formation of the $\alpha-\mathrm{Al}_{2} \mathrm{O}_{3}$ layer.
\end{abstract}

\section{Y. Wu $(\bowtie)$}

School of Materials Science and Engineering, Shanghai Institute of Technology,

No. 120, Cao Bao Road, Shanghai 200235, People's Republic of China

e-mail: science2008@live.cn

Y. Wu

Advanced Technology \& Materials Co., Ltd., China Iron \& Steel Research Institute Group,

No.76 Xueyuan Nanlu, Haidian, Beijing 100081, People's Republic of China

Y. Wu · Y. M. Wang

Research Group of Interface Control Engineering, Graduate School of Engineering,

Hokkaido University, Kita-13, Nishi-8, Kita-ku, Sapporo 060-8628, Japan

G. M. Song

Department of Materials Science and Engineering, Delft University of Technology,

Mekelweg 2, 2628CD Delft, The Netherlands

X. W. Li

Institute of Materials Physics and Chemistry, College of Sciences, Northeastern University, P.O. Box 104, No. 3-11, Wenhua Road, Shenyang 110004, People's Republic of China 
Keywords Single-crystal Ni-based superalloy · Diffusion barrier · Coating ·

Oxidation - Microstructure $\cdot$ Electron probe microanalysis (EPMA)

\section{Introduction}

Ni-based superalloys have been used for blades and vanes along with the thermal barrier coatings (TBCs) in industrial gas turbine engines and aero-engines because of their high creep strength and good temperature corrosion resistance [1]. The TBCs are typically two-layered, metallic bond-coat layer consists of Al-pack cementation, $\beta-\mathrm{Ni}(\mathrm{Pt}) \mathrm{Al}$ and $\mathrm{MCrAlY}(\mathrm{M}=\mathrm{Co}, \mathrm{Ni}$ or $\mathrm{NiCo})$ for preventing the internal oxidation of substrate, and $\mathrm{Y}_{2} \mathrm{O}_{3}$ stabilized $\mathrm{ZrO}_{2}$ is used as a ceramic topcoat material for insulating heat conduction [2]. The TBCs and its degradation modes are usually divided into two groups. One is exfoliation of the ceramic topcoat due to thermally grown oxide (TGO) and thermal stress, and the other is changes in the microstructure of the alloy substrate due to mutual diffusion with the bond-coat, resulting in precipitation of topologically close-packed (TCP) phases [3]. The life span of the TBCs is controlled by maintaining a reservoir of $\mathrm{Al}$ that forms a protective $\alpha-\mathrm{Al}_{2} \mathrm{O}_{3}$ scale on the surface. Loss of $\mathrm{Al}$ from the coatings occurs by exfoliation of the $\alpha-\mathrm{Al}_{2} \mathrm{O}_{3}$ scale due to thermal cycling and also by interdiffusion between the coating and substrate. Moreover, the inward diffusion of $\mathrm{Al}$ to the alloy substrate and outward diffusion of the alloying elements in the substrate could lead to decreases in the mechanical properties of the alloy substrate [3]. Due to acceleration of interdiffusion between the alloy substrate and the bond-coat, the precipitation of detrimental phases from the substrate occurs, and the rapid growth of a thermally grown oxide on the bond-coat results in enhancement of the top-coat spallation [4].

Some studies on the oxidation behavior of both base and coated SC Ni-based superalloys have been investigated by several researchers [5-31]. In previous papers by some present authors $[5,6]$, a new Re-modified Ni-aluminide coating has been adopted, in which a $\mathrm{Re}-\mathrm{Cr}-\mathrm{Ni}$ ( $\sigma$-phase) layer acts as a diffusion barrier to suppress the outer-diffusion of $\mathrm{Ni}$ from the substrate. The oxidation behavior of the coated TMS-82+ superalloy exposed at $900{ }^{\circ} \mathrm{C}$ was studied by focusing on the microstructural evolution of the diffusion barrier and its effect on the oxidation resistance. Considering its actual application environment, the exposure temperature of the Ni-based superalloy in the present study is increased to $1150{ }^{\circ} \mathrm{C}$, and the oxidation behavior of a SC Ni-based TMS-82+ superalloy under cyclic air environment is studied by analyzing the mass change and microstructural evolution of the oxide scale as well as the role of the Re-based phase in the bond-coat between the $\mathrm{Ni}-\mathrm{Al}$ coating and alloy substrate.

\section{Experimental Procedures}

The experimental alloy used in the present study was prepared from the secondgeneration SC TMS-82+ superalloy (Al:12.24, Co:8.12, Cr:5.42, Hf:0.05, Mo:1.14, 
Re:0.82, Ta:2.20, W:2.90, Y:004, Zr:0.01, Ni:bal.) (at.\%), which developed by NIMS (National Institute for Materials Science) and Toshiba collaboration, Japan. TMS-82 + superalloy provides creep strength $300{ }^{\circ} \mathrm{C}$ higher than CMSX-4 in temperature capability at a stress level of approximately 137.2 MPa. TMS-82+ superalloy has very good high temperature corrosion resistance and is suitable for turbine blades and vanes in industrial gas turbines and aero-engines [32]. Priors to the coating, the specimens were cut into $\phi 12 \times 1 \mathrm{~mm}$ plates from the alloy bars, and the surface was ground to a mirror-like surface by SiC papers up to No. 1200 mesh finish followed by ultrasonic cleaning with acetone in an ultrasonic bath. The coating was obtained by the following processes. One route was to obtain the coated superalloy without the diffusion barrier. A Ni film of about $15 \mu \mathrm{m}$ thickness was electroplated on the specimen surface in a Watt's solution at a bath temperature of $50{ }^{\circ} \mathrm{C}$ for $75 \mathrm{~min}$ with a current density of $20 \mathrm{~mA} / \mathrm{cm}^{2}$ before Ni strike for $30 \mathrm{~s}$ with a current density of $500 \mathrm{~mA} / \mathrm{cm}^{2}$. The coating was obtained on the specimens by electroplating of $\mathrm{Ni}$ followed by Al-pack cementation. The high $\mathrm{Al}$ activity pack cementation was carried out in a vacuum of $10^{-3} \mathrm{~Pa}$ at $800^{\circ} \mathrm{C}$ for $20 \mathrm{~min}$ by burying the Ni-plated specimens into a mixture of $\mathrm{Al}$ metal powder (15 wt $\%$ ), $\mathrm{NH}_{4} \mathrm{Cl}(5 \mathrm{wt} \%)$ as an activator, and $\mathrm{Al}_{2} \mathrm{O}_{3}$ powder as an anti-sintering agent. The compositions of the coating were determined to be (71-98) at.\% $\mathrm{Ni}$ and $\sim 40$ at. $\% \mathrm{Ni}-60 \mathrm{at} . \% \mathrm{Al}$ from the substrate, namely, the coating consisted of an internal Ni-rich layer and an external $\mathrm{Ni}_{2} \mathrm{Al}_{3}$ layer [6].

Another route was to obtain the coated superalloy with the $\mathrm{Re}-\mathrm{Cr}-\mathrm{Ni}$ diffusion barrier. The specimen was firstly electroplated in a $\mathrm{Re}-\mathrm{Ni}$ solution at a bath temperature of $50{ }^{\circ} \mathrm{C}$ for $15 \mathrm{~min}$ with a current density of $20 \mathrm{~mA} / \mathrm{cm}^{2}$, and then Ni-electroplating was performed in a Watt's solution at a bath temperature of $50{ }^{\circ} \mathrm{C}$ for $75 \mathrm{~min}$ with a current density of $20 \mathrm{~mA} / \mathrm{cm}^{2}$. The $\mathrm{Cr}$-pack diffusion was carried out in a vacuum of $10^{-6} \mathrm{~Pa}$ at $1280^{\circ} \mathrm{C}$ for $10 \mathrm{~h}$ by embedding the Ni-plated specimens into an $\mathrm{Al}_{2} \mathrm{O}_{3}$ container with a mixture of $\mathrm{Cr}$ vapor source of $\mathrm{Ni}-30 \mathrm{Cr}$ powder as an activator and $\mathrm{Ni}_{2} \mathrm{Al}_{3}$ powder as an anti-sintering agent. After cleaning $\mathrm{Re}-\mathrm{Cr}-\mathrm{Ni}$ coated specimen slightly $\mathrm{Ni}$ electroplating and Al-pack cementation was performed. The constituents of the coating were in the order of $\mathrm{Re}-\mathrm{Cr}-\mathrm{Ni}$ diffusion barrier layer, $\mathrm{Ni}-\mathrm{Cr}-\mathrm{Al}$ layer and $\mathrm{Ni}_{2} \mathrm{Al}_{3}$ layer from the substrate. The corresponding compositions of above layer were $\sim 41$ at. $\% \mathrm{Re}-21$ at. $\% \mathrm{Cr}-17 \mathrm{at} . \% \mathrm{Ni}, 75 \mathrm{at} . \% \mathrm{Ni}-$ 11 at. $\% \mathrm{Cr}-9$ at. $\% \mathrm{Al}$, and $42 \mathrm{at} . \% \mathrm{Ni}-58 \mathrm{at} . \% \mathrm{Al}$, respectively [6]. The details of the forming process of the $\mathrm{Re}-\mathrm{Cr}-\mathrm{Ni}$ phase are described elsewhere [3, 5-7]. Apart from the $\mathrm{Ni}-\mathrm{Al}$ coated specimens, the uncoated base superalloy was used to compare the oxidation behavior.

Oxidation tests were carried out in air at $1150{ }^{\circ} \mathrm{C}$ for $200 \mathrm{~h}$ under a thermal cycling condition. The specimens were suspended with a platinum wire in $\mathrm{Al}_{2} \mathrm{O}_{3}$ crucibles, and were put into the furnace to expose in air. The specimens were regularly removed from the furnace at intervals of $0-30 \mathrm{~h}$ followed by air cooling to room temperature. The mass change of specimens was measured using a balance (HR-202) with $0.01 \mathrm{mg}$ accuracy at room temperature. Phase identification of the oxide scales was performed by X-ray diffraction (XRD, D/Max 2500PC Rigaku) using $\mathrm{Cu}\left(K_{\alpha}\right)$ as a target. Surface and cross-sectional morphologies were observed using a JEOL scanning electron microscope (SEM, JSM-6500) with 
energy-dispersive X-ray spectrometry (EDS). The elemental concentration profiles in the cross-sectional layer of the oxides were measured quantitatively by electron probe microanalysis (EPMA, JEOL JXA-81150M WD/ED) at $15 \mathrm{kV}$ and $3.0 \times 10^{-8} \mathrm{~A}$.

\section{Results and Discussion}

The oxidation resistance of the SC Ni-based superalloy was greatly improved by the $\mathrm{Ni}-\mathrm{Al}$ coating with the Re-based diffusion barrier. Figure 1 shows the mass changes per unit surface area for the base superalloy, $\mathrm{Ni}-\mathrm{Al}$ coated and $\mathrm{Re}$-based plus $\mathrm{Ni}-\mathrm{Al}$ coated superalloy after cyclic oxidation at $1150{ }^{\circ} \mathrm{C}$ for $200 \mathrm{~h}$ in air. The mass gain for the $\mathrm{Ni}-\mathrm{Al}$ coating with the Re-based diffusion barrier showed a gradual increase with the exposure time, but the base superalloy showed a negative mass gain due to extensive oxide spallation after $40 \mathrm{~min}$, and the $\mathrm{Ni}-\mathrm{Al}$ coated superalloy without the diffusion barrier started to spall slightly after about $90 \mathrm{~h}$. Since this spallation was less dramatic, it was not very visible in the gravimetry data before $170 \mathrm{~h}$. After $200 \mathrm{~h}$ exposure in air, the mass gains for the specimens with/without the diffusion barrier were 48.5 and $23.6 \mathrm{~g} / \mathrm{m}^{2}$, respectively, but, it was $-50.4 \mathrm{~g} / \mathrm{m}^{2}$ for the base superalloy. The highest oxidation rate for the base superalloy was obtained at an initial exposure period ( 0 cycle, namely, the samples were only heated up and cooled down), for example, the mass gains for the base, the coated specimen with/ without the diffusion barrier were $5.3,1.5$ and $1.5 \mathrm{~g} / \mathrm{m}^{2}$, respectively. The values for the parabolic rate constant, $K \mathrm{p}$, of about $95.6,14.1$ and $11.1 \mathrm{~g}^{2} / \mathrm{m}^{4} \mathrm{~h}$ were obtained for the base superalloy and the coated SC Ni-based superalloy with/without the diffusion barrier exposed at an initial period, respectively, which indicates a rapid growth rate of the oxides for the base superalloy than the coated ones. It is believed that the oxidation kinetics of the base superalloy at an initial period was controlled by the $\mathrm{NiO}$ growth due to fast diffusion of $\mathrm{Ni}$.

The complex oxide produces on the base superalloy after $200 \mathrm{~h}$ were determined. Figure 2 shows the XRD spectra of the oxide scales formed on the base and $\mathrm{Ni}-\mathrm{Al}$ coated superalloy without/with the Re-based diffusion barrier at $1150{ }^{\circ} \mathrm{C}$ after $200 \mathrm{~h}$ cyclic exposure in air. On the base superalloy in Fig. 2a, the peaks of $\mathrm{NiO}$ showed the strongest intensity. Complex oxide products including predominately $\mathrm{NiO}$, some $\mathrm{CrTaO}_{4}, \alpha-\mathrm{Al}_{2} \mathrm{O}_{3}, \mathrm{Cr}_{2} \mathrm{O}_{3}$, a minor of spinels of $(\mathrm{Ni}, \mathrm{Co}) \mathrm{Al}_{2} \mathrm{O}_{4}, \mathrm{NiCr}_{2} \mathrm{O}_{4}$, $\mathrm{AlTaO}_{4}, \theta-\mathrm{Al}_{2} \mathrm{O}_{3}$ and $\mathrm{W}_{20} \mathrm{O}_{58}$ were detected. On the contrary, for the $\mathrm{Ni}-\mathrm{Al}$ coated specimens in Fig. 2b, c, the oxide products were simple, the $\alpha-\mathrm{Al}_{2} \mathrm{O}_{3}$, a minor of $\mathrm{NiAl}_{2} \mathrm{O}_{4}$ and $\mathrm{NiO}$ were detected. Peaks of $\mathrm{NiAl}$ were detected in both $\mathrm{Ni}-\mathrm{Al}$ coated superalloy, particularly in the $\mathrm{Ni}-\mathrm{Al}$ coating with the Re-based diffusion barrier, see Fig. 2c, showing a thinner oxide scale. It seems that the ratios of peaks height of $\mathrm{Al}_{2} \mathrm{O}_{3} / \mathrm{NiO}$ and $\mathrm{Al}_{2} \mathrm{O}_{3} / \mathrm{NiAl}_{2} \mathrm{O}_{4}$ on the $\mathrm{Ni}-\mathrm{Al}$ coating with the Re-based diffusion barrier are almost identical to the $\mathrm{Ni}-\mathrm{Al}$ coated one without the Re-based diffusion barrier, indicating a large amount of $\alpha-\mathrm{Al}_{2} \mathrm{O}_{3}$ in both coatings. Thus, the formation of non-protective scale mainly induced the poor oxidation resistance of the base superalloy. It is expected that the oxidation resistance of the $\mathrm{Ni}-\mathrm{Al}$ coated 


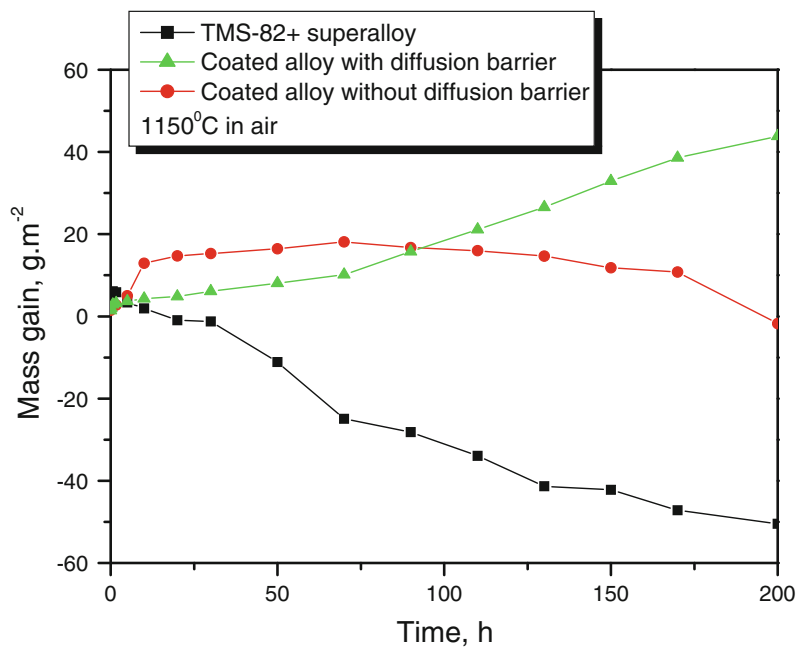

Fig. 1 Oxidation kinetics of the SC Ni-based superalloy in air at $1150{ }^{\circ} \mathrm{C}$ for $200 \mathrm{~h}$ under cyclic oxidation

superalloy with/without the diffusion barrier is improved by the formation of a dense $\alpha-\mathrm{Al}_{2} \mathrm{O}_{3}$ scale.

The $\mathrm{Ni}-\mathrm{Al}$ coating with the Re-based diffusion barrier on the SC Ni-based superalloy supplied $\mathrm{Al}$ for the growth of $\alpha-\mathrm{Al}_{2} \mathrm{O}_{3}$. Figure 3 shows SEM micrographs of the surface morphology of the oxide scales of the base and $\mathrm{Ni}-\mathrm{Al}$ coated $\mathrm{SC}$ Ni-based superalloy without/with the diffusion barrier at $1150{ }^{\circ} \mathrm{C}$ after $200 \mathrm{~h}$ cyclic exposure. As shown in Fig. 3a, the severe oxide spallation on the specimen surface was observed due to non-protective scale. The unexfoliated oxides were typically $\mathrm{NiO}$. For the Ni-Al coating without the Re-based diffusion barrier in Fig. 3b, the oxide spllation occurred in the some zones on the specimen surface, from the unexfoliated areas inserted in this figure, the agglomerate-type oxides covered the surface of the specimen were determined to be rich in oxygen and nickel with a minor of aluminum. As for the $\mathrm{Ni}-\mathrm{Al}$ coating with the Re-based diffusion barrier in Fig. 3c, typical morphologies of blocky-type oxides were observed on the surface of specimen, and they were determined to be $\alpha-\mathrm{Al}_{2} \mathrm{O}_{3}$. An inserted micrograph at high magnification demonstrated that almost no spallation occurred on the sample surface in the present exposure condition.

The scale formed on the base superalloy showed a complex structure. Figure $4 \mathrm{a}$ shows a SEM micrograph of the cross-sectional morphology on the base SC Ni-based superalloy after $200 \mathrm{~h}$ cyclic oxidation at $1150{ }^{\circ} \mathrm{C}$ in air. The corresponding concentration profiles of the elements by EPMA are shown in Fig. 4b. The thickness of oxide scale was about $30 \mu \mathrm{m}$. Main elements $\mathrm{Ni}, \mathrm{O}$ and $\mathrm{Al}$ together with minor elements such as $\mathrm{Cr}, \mathrm{Ta}, \mathrm{Co}, \mathrm{Mo}, \mathrm{Re}$ and $\mathrm{W}$ were detected in the scale. A total of three layers with different chemical compositions were identified for the oxide scale. Starting from the substrate, the oxide scales consisted of Al-rich layer, mixed layer and Ni-rich layer. The existence of the outer layer of 

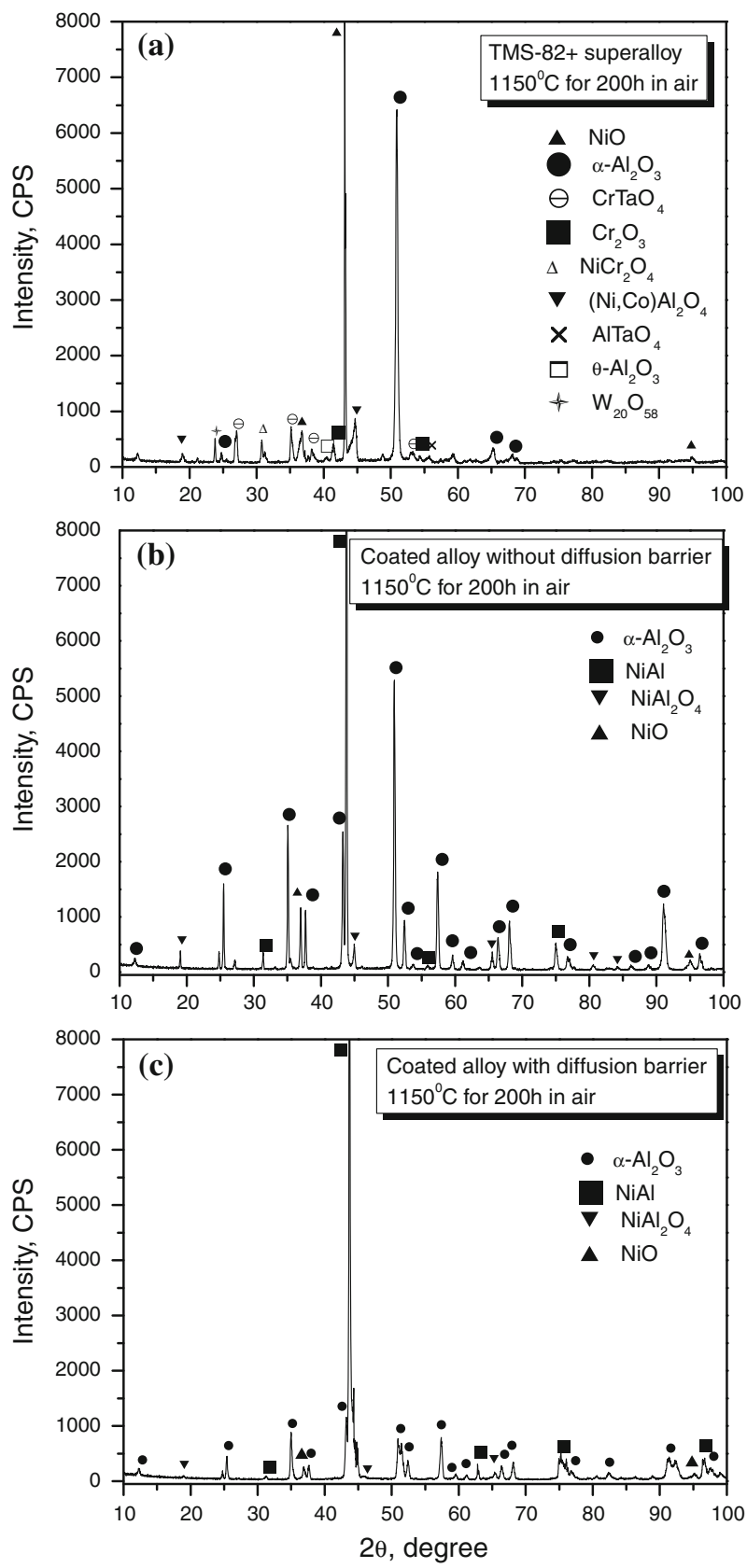

Fig. 2 X-ray diffraction spectra of the oxide scales for the SC Ni-based superalloy (a), the Ni-Al coated (b) and the $\mathrm{Re}-\mathrm{Ni}-\mathrm{Cr}$ and $\mathrm{Ni}-\mathrm{Al}$ coated alloy (c) after $200 \mathrm{~h}$ exposure at $1150{ }^{\circ} \mathrm{C}$ in air 
Fig. 3 SEM micrographs of the surface morphologies of the oxide scales formed at $1150{ }^{\circ} \mathrm{C}$ after $200 \mathrm{~h}$ cyclic oxidation in (a) base alloy, (b) $\mathrm{Ni}-\mathrm{Al}$ coated (inserted a micrograph showing unexfoliated zone) and

(c) $\mathrm{Re}-\mathrm{Ni}-\mathrm{Cr}$ and $\mathrm{Ni}-\mathrm{Al}$ coated alloy in air (inserted a micrograph at high magnification)
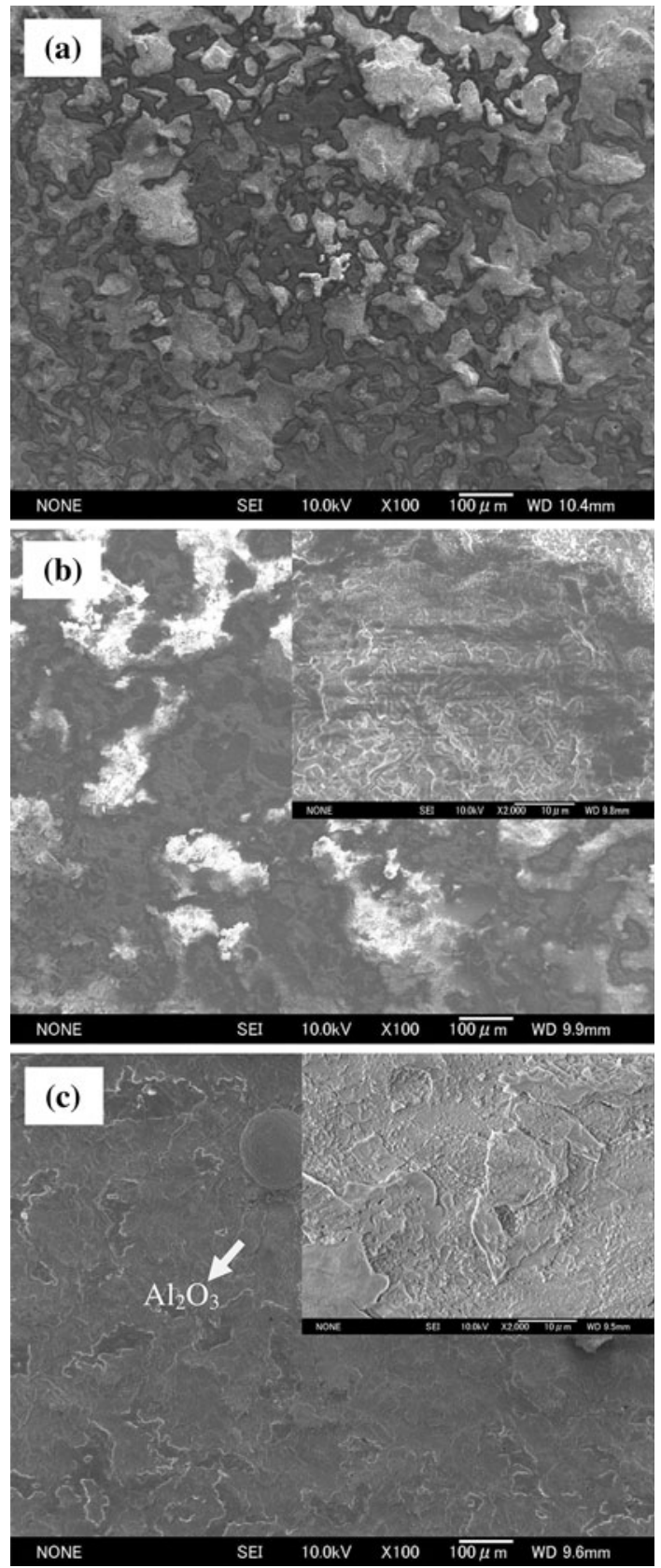

$\mathrm{NiO}$ was common to the Ni-based alloys. The formation of $(\mathrm{Ni}, \mathrm{Co}) \mathrm{O}$ on the surface of the specimen due to fast diffusion of Ni indicated that the oxidation kinetics of the superalloy at the initial period was controlled by the $\mathrm{NiO}$ growth. The intermediate layer contained main elements of $\mathrm{Ni}, \mathrm{Al}$, and $\mathrm{O}$ with trace elements of 


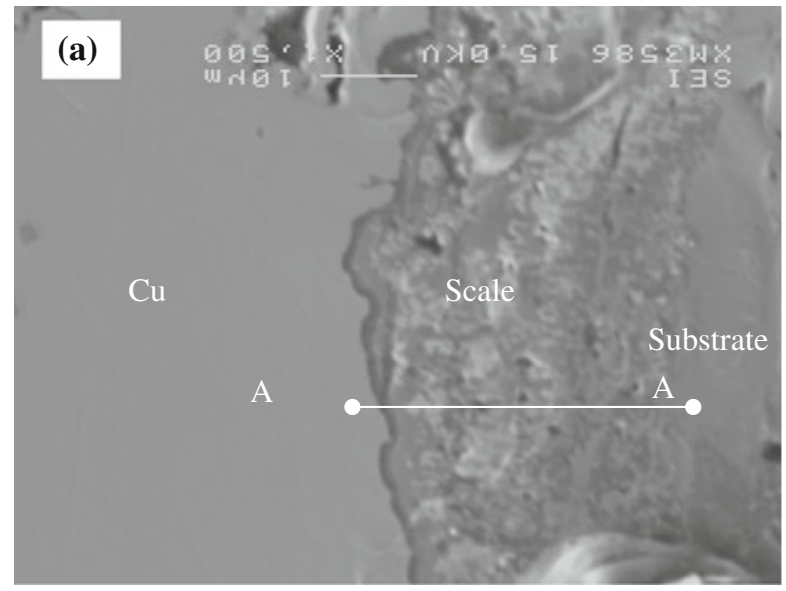

(b)

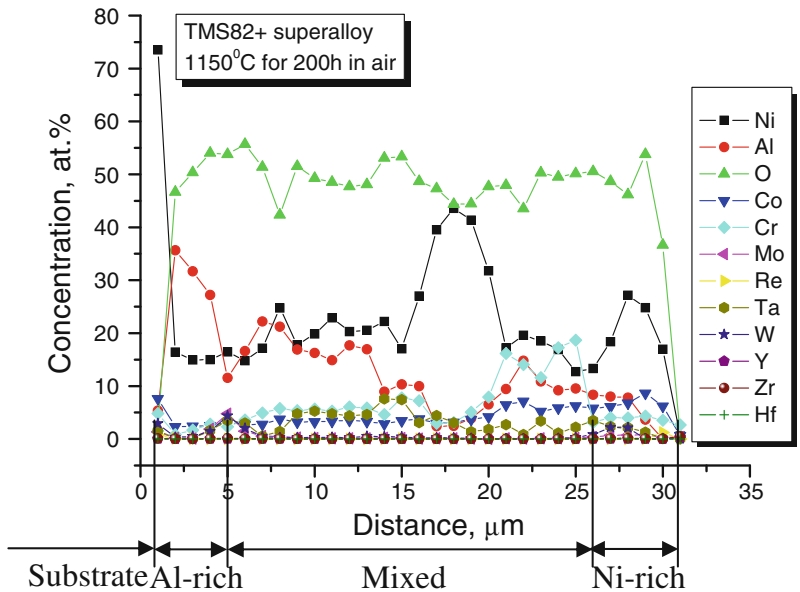

Fig. 4 SEM micrograph of the cross-sectional morphology (a) and concentration profiles and (b) of each element measured along the A-A line for the SC TMS-82+ superalloy after $200 \mathrm{~h}$ cyclic oxidation at $1150{ }^{\circ} \mathrm{C}$ in air

$\mathrm{Cr}, \mathrm{Ta}, \mathrm{Co}, \mathrm{Mo}, \mathrm{Re}$ and W. The mixture oxides consisted mainly of $\mathrm{CrTaO}_{4}$, $\mathrm{AlTaO}_{4}, \mathrm{Cr}_{2} \mathrm{O}_{3}$, spinels and $\mathrm{Al}_{2} \mathrm{O}_{3}$. According to the concentration of $\mathrm{Cr}$ and $\mathrm{Al}$ in the $\mathrm{Ni}-\mathrm{Cr}-\mathrm{Al}$ alloy [33], the oxidation behavior in the present study was controlled by transport through the $\mathrm{NiO}$ layer. The spinels of $\mathrm{NiCr}_{2} \mathrm{O}_{4}$ and $(\mathrm{Ni}, \mathrm{Co}) \mathrm{Al}_{2} \mathrm{O}_{4}$ were produced by the reaction of $\mathrm{NiO}$ with $\mathrm{Cr}_{2} \mathrm{O}_{3}$ and $(\mathrm{Ni}, \mathrm{Co}) \mathrm{O}$ with $\mathrm{Al}_{2} \mathrm{O}_{3}$, respectively. With thickening of the oxide scale, the inward flux of oxygen was reduced further, which is beneficial to the preferential oxidation of $\mathrm{Al}$, leading to an innermost layer of $\alpha-\mathrm{Al}_{2} \mathrm{O}_{3}$ next to the substrate.

The Ni-Al coated superalloy without the Re-based diffusion barrier formed a non-protective oxide scale although a large amount of $\mathrm{Al}_{2} \mathrm{O}_{3}$ was obtained. Figure 5 shows a SEM micrograph of the unexfoliated cross-sectional morphology and its 


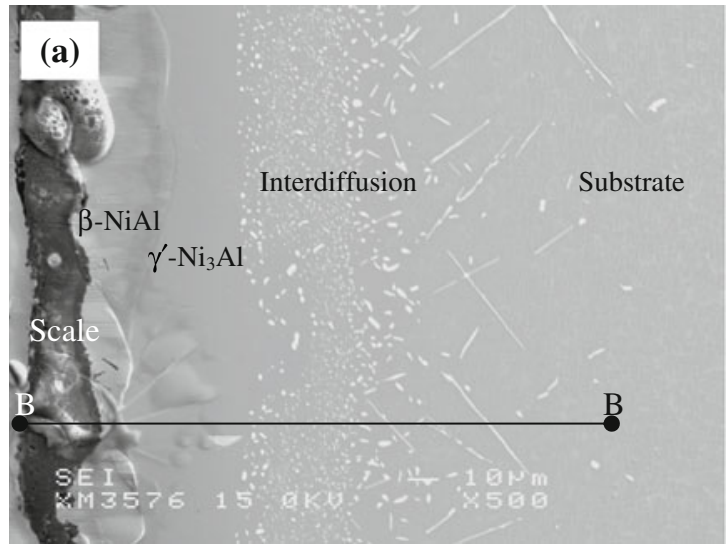

(b)

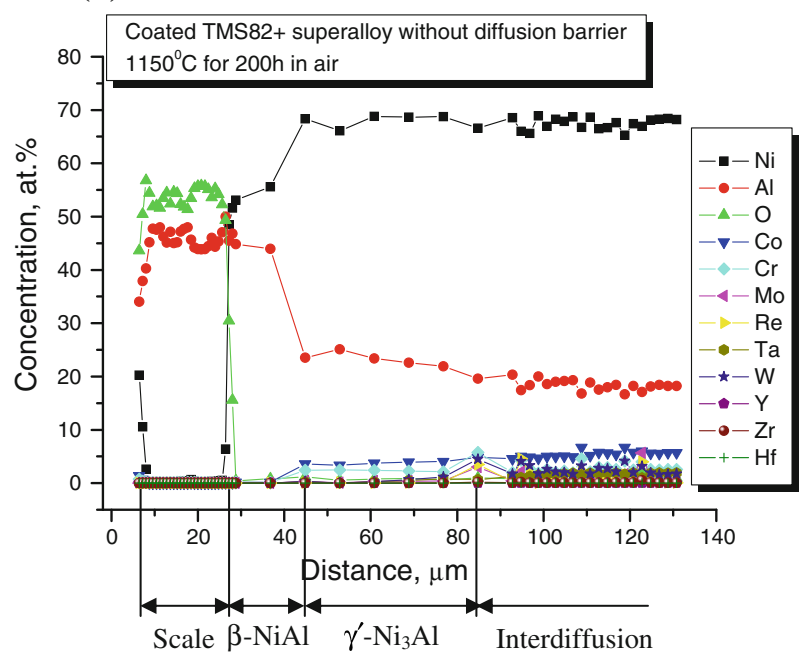

Fig. 5 SEM micrograph of the unexfoliated cross-sectional morphology (a) and concentration profiles (b) of each element measured along the B-B line in the $\beta$-NiAl coated SC TMS-82+ superalloy after $200 \mathrm{~h}$ cyclic oxidation at $1150{ }^{\circ} \mathrm{C}$ in air

corresponding concentration profiles of the elements by EPMA of the $\mathrm{Ni}-\mathrm{Al}$ coated SC Ni-based superalloy without the diffusion barrier after $200 \mathrm{~h}$ cyclic oxidation at $1150{ }^{\circ} \mathrm{C}$ in air. Four different layers from the substrate were observed: interdiffusion zone, $\gamma^{\prime}-\mathrm{Ni}_{3} \mathrm{Al}, \beta-\mathrm{NiAl}$ coating and TGO scale. From the results of EPMA, the chemical composition in each layer was determined. The external oxide scale grew thicker, contained $\mathrm{Ni}, \mathrm{Al}$ and $\mathrm{O}$, and was also accompanied by local spallation. The TGO scale was composed of $\mathrm{Al}_{2} \mathrm{O}_{3}, \mathrm{NiAl}_{2} \mathrm{O}_{4}$ and $\mathrm{NiO}$ layer. The thickness of the $\gamma^{\prime}-\mathrm{Ni}_{3} \mathrm{Al}, \beta$-NiAl and TGO scale layer was approximately 40,18 and $20 \mu \mathrm{m}$, respectively. A thick TGO layer is mainly responsible for the oxide spallation. A wide interdiffusion zone (about $80 \mu \mathrm{m}$ ) contained large acicular precipitates was 
evident, which was particularly detrimental to the mechanical properties of the alloy substrate. These phases are potentially damaging for crack initiators because of their brittle nature $[13,14]$. According to the oxidation map of the $\mathrm{Ni}-\mathrm{Al}$ alloys reported by Pettit [34], the Ni-(3-35 wt\%)-Al alloys are oxidized from 900 to $1300{ }^{\circ} \mathrm{C}$ by three different mechanisms which depend on the temperature of oxidation and the alloy composition. The oxide map divided the constitution of the oxide scale into three regions: (I) $\mathrm{NiO}$ scale with internal oxidation of $\mathrm{Al}$, (II) $\mathrm{Al}_{2} \mathrm{O}_{3}$ formation initially followed by duplex $\mathrm{NiO}$ and $\mathrm{NiAl}_{2} \mathrm{O}_{4}$, with internal oxidation of $\mathrm{Al}$ after longer oxidation, and (III) exclusive $\mathrm{Al}_{2} \mathrm{O}_{3}$ scale formation. For the present case, the mechanism located in the region II, which a thick external scale containing $\mathrm{NiO}$, $\mathrm{NiAl}_{2} \mathrm{O}_{4}$ and $\mathrm{Al}_{2} \mathrm{O}_{3}$ develops. Hence, this non-protective scale is liable to exfoliate during oxidation.

The superalloy coated with a Re-based alloy layer and an Al reservoir layer formed a protective $\alpha-\mathrm{Al}_{2} \mathrm{O}_{3}$ scale on the coating during oxidation although a minor $\mathrm{NiO}$, $\mathrm{NiAl}_{2} \mathrm{O}_{4}$ was detected. The $\mathrm{Al}$ reservoir layer on the Re-based alloy layer contains $42 \mathrm{Al}, 4 \mathrm{Cr}$ and the remainder Ni. The thickness of the interdiffusion zone significantly decreased for the superalloy containing the Re-based diffusion barrier layer, it was much lower than that in the $\mathrm{Ni}-\mathrm{Al}$ coated superalloy without the diffusion barrier, 10 $\mu \mathrm{m}$, see acicular precipitates in white contrast in Fig. $6 \mathrm{~b}$, which means the precipitate phases was remarkably reduced. It should be emphasized that there is little change in the structure and concentration profiles of any of the elements in the alloy substrate after oxidation at $1150{ }^{\circ} \mathrm{C}$ for $200 \mathrm{~h}$. Comparing with the TGO thickness for the $\mathrm{Ni}-$ Al coated superalloy without the diffusion barrier in Fig. 6a, the TGO thickness for the $\mathrm{Ni}-\mathrm{Al}$ coated superalloy with the diffusion barrier is much thinner, it was about 2 $\mu \mathrm{m}$. Thus, a dense and thin $\alpha-\mathrm{Al}_{2} \mathrm{O}_{3}$ layer is responsible for good oxidation resistance in the $\mathrm{Ni}-\mathrm{Al}$ coated superalloy with the Re-based diffusion barrier.

As reported by some of present authors [3,5-7], a thick $\mathrm{Al}_{2} \mathrm{Ni}_{3}$ layer formed on the surface of the SC Ni-based superalloy after the $\mathrm{Ni}-\mathrm{Al}$ coating. Applying the $\mathrm{Re}-\mathrm{Cr}-\mathrm{Ni}$ plus $\mathrm{Ni}-\mathrm{Al}$ coating process, a diffusion barrier layer of the $\sigma$-phase $\mathrm{Re}-$ $\mathrm{Cr}-\mathrm{Ni}$ and $\mathrm{N} \mathrm{Ni}_{2} \mathrm{Al}_{3}$ layer were obtained. During exposure at $1150{ }^{\circ} \mathrm{C}$, the phase transformation from $\mathrm{Ni}_{2} \mathrm{Al}_{3}$ to $\beta$-NiAl occurred by the following equation under assumptions of stoichiometric compounds.

$$
\mathrm{Ni}_{2} \mathrm{Al}_{3} \rightarrow 2 \mathrm{NiAl}+\mathrm{Al}
$$

During oxidation $\mathrm{Al}$ was consumed by the formation of $\mathrm{Al}_{2} \mathrm{O}_{3}$ and $\mathrm{Al}$ diffusion toward the inner layer. The formation of a thin and dense $\alpha-\mathrm{Al}_{2} \mathrm{O}_{3}$ layer resulted in an improvement of oxidation resistance of the $\mathrm{Ni}-\mathrm{Al}$ coated superalloy with the Re-based diffusion barrier. The coated superalloy with the Re-based diffusion barrier showed gradual mass gains and the scale consisted mainly of $\alpha-\mathrm{Al}_{2} \mathrm{O}_{3}$ oxides, indicating much better oxidation resistance. For the base superalloy and the $\mathrm{Ni}-\mathrm{Al}$ coated superalloy without the diffusion barrier, however, the mass change curve showed negative increase due to severe spallation from thick oxide scales. A fast growth rate of the oxides was observed at the initial period for the base superalloy, which contains coarse grains of complex oxides. Therefore, the $\mathrm{Ni}-\mathrm{Al}$ coating with the Re-based diffusion barrier process is effective in obtaining a dense $\alpha-\mathrm{Al}_{2} \mathrm{O}_{3}$ layer, which is responsible for the improvement of the oxidation resistance. 

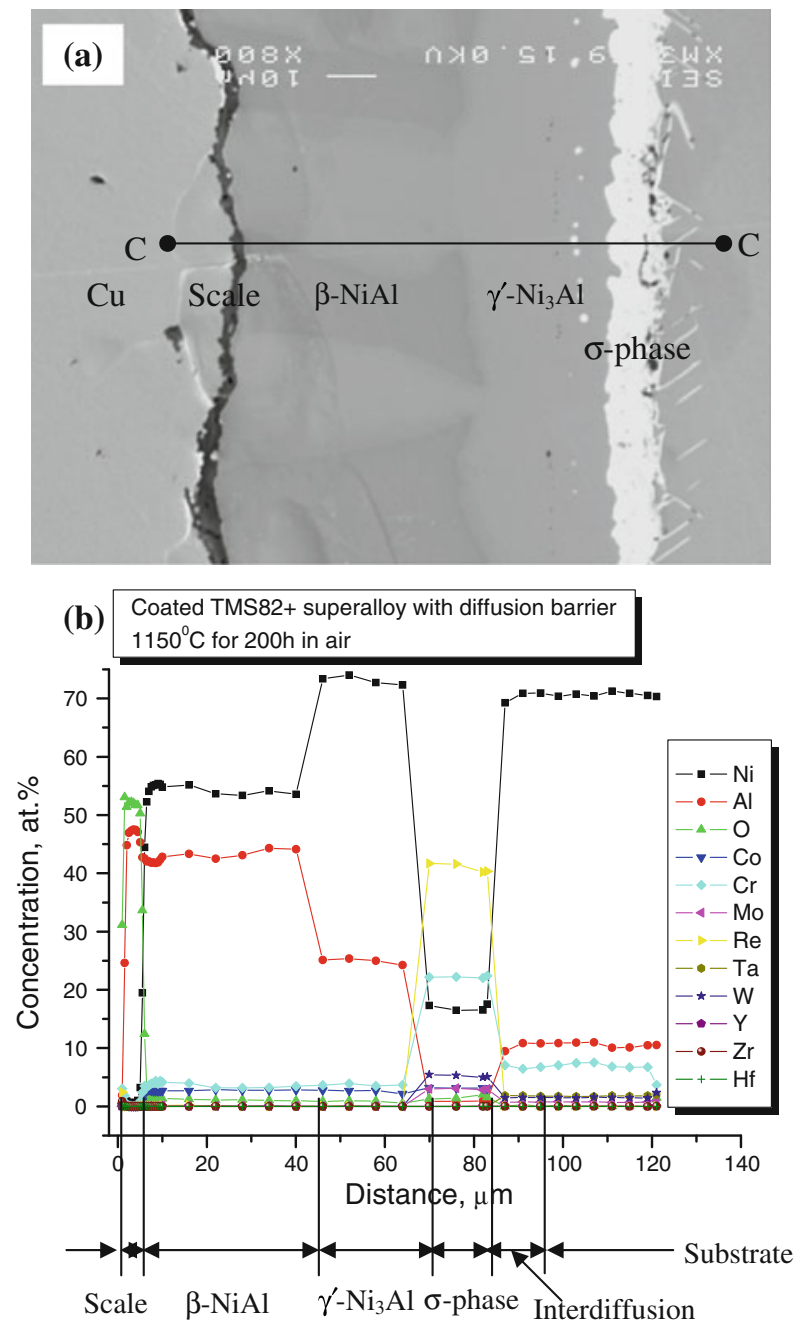

Fig. 6 SEM micrograph of the cross-sectional morphology (a) and concentration profiles (b) of each element measured along the $\mathrm{C}-\mathrm{C}$ line in the Re-based diffusion barrier/ $\beta$-NiAl coated SC TMS- $82+$ superalloy after $200 \mathrm{~h}$ cyclic oxidation at $1150{ }^{\circ} \mathrm{C}$ in air

In order to improve the oxidation resistance of materials in gas turbine engines, the oxidation-resistant coating on the high strength, SC Ni-base superalloy components are applied. The coatings are based on the intermetallic compound $\mathrm{NiAl}$, which is oxidation resistant because under oxidizing conditions a protective scale can be formed, which is composed principally of aluminum oxide. In the present study, a diffusion barrier layer of the $\mathrm{Re}-\mathrm{Cr}-\mathrm{Ni}$ phase was stable after exposure at $1150{ }^{\circ} \mathrm{C}$. The role of the diffusion barrier layer was evident for blocking the interdiffusion of the elements between the substrate and the bond-coat, as shown in Fig. 6, the width of the distribution zone and the density of the precipitates was 
obviously reduced, indicating an effective barrier for interdiffusion of the alloying elements. For the coated superalloy without the diffusion barrier, however, a wide interdiffusion zone formed, which obviously damages the mechanical properties of the substrate superalloy. During exposure at high temperature, the interdiffusion zone was represented as containing precipitate phases of the Ni-based superalloy. Extending the duration, further interdiffusion can occur as a result of solid-state diffusion across the substrate/coating interface. This additional migration of elements across the substrate-coating interface can sufficiently alter the chemical composition and microstructure of both the bond coat and the substrate in the vicinity of the interface to have deleterious results. Similar study on the effect of the diffusion barrier on interdiffusion of the alloying elements was reported by $\mathrm{Wu}$ et al. [35]. An Ir-Ta modified aluminide coating as an effective diffusion barrier on SC Ni-based superalloy TMS-75 was developed. The Ir-Ta-Al coated TMS-75 had better thermal cyclic oxidation resistance than simply aluminized TMS-75, which was mainly due to a large decrease of detrimental TCP phases in the interdiffusion of solute elements.

The increase in operating temperature for current turbine systems has brought about serious problems, such as the acceleration of interdiffusion between the substrate and the bond-coat, which may promote the precipitation of detrimental phases in the substrate, and the rapid growth of a TGO on the bond-coat surface. In the present study, the Re-based diffusion barrier layer of the $\sigma$-phase was obtained to block the interdiffusion of the alloying elements between the substrate and the bond-coat, and reduce the precipitates of the detrimental phases. It is thus expected to further enhance the adherence strength between the top-coat and the bond-coat, and accordingly prolongs the service life of TBCs.

\section{Conclusions}

In summary, the oxidation resistance of the SC Ni-based TMS-82+ superalloy was effectively improved by $\mathrm{Ni}-\mathrm{Al}$ coating with a Re-based diffusion barrier layer due to the formation of a protective $\alpha-\mathrm{Al}_{2} \mathrm{O}_{3}$ scale. The base and $\mathrm{Ni}-\mathrm{Al}$ coated superalloy were significantly oxidized, accompanied by severe oxide spallation and slight spallation after $40 \mathrm{~min}$ and $90 \mathrm{~h}$, respectively. After oxidation at $1150{ }^{\circ} \mathrm{C}$ for $200 \mathrm{~h}$, the Re-based diffusion barrier layer was stable and effectively retarded the inward diffusion of $\mathrm{Al}$ from the $\mathrm{Ni}-\mathrm{Al}$ and outward diffusion of alloying elements in the alloy substrate, resulting in a reduced thickness of interdiffusion zone with small amount of detrimental precipitates in the bond-coat and higher content of $\mathrm{Al}$ in the $\mathrm{Ni}-\mathrm{Al}$ coating.

Acknowledgements This work was financially supported by The Program for Professor of Special Appointment (Eastern Scholar) at Shanghai Institutions of Higher Learning, China (No. DF2009-01), and Innovation Program of Shanghai Municipal Education Commission, China (No. 10ZZ126). This work described in this paper was also partly supported by the Program for New Century Excellent Talents (NCET-07-0162) in University, Ministry of Education, P.R. China, and by the Fundamental Research Funds for the Central Universities of China under Grant No. N090505001. Sincere thanks also go to Prof. T. Narita for useful discussion on the present work. 


\section{References}

1. J. K. Tien and T. Caulfield, Superalloys, Supercomposites and Superceramics (Academic Press, San Diego, 1989).

2. A. Suzuki, F. Wu, H. Murakami, and H. Imai, Science and Technology of Advanced Materials 5, 555 (2004).

3. T. Narita, T. Izumi, T. Nishimoto, Y. Shibata, K. Z. Thosin, and S. Hayashi, Materials Science Forum 522-523, 1 (2006).

4. N. M. Yanar, G. H. Meier, and F. S. Pettit, Scripta Materialia 46, 325 (2002).

5. T. Narita, M. Shoji, Y. Hisamatsu, D. Yoshida, M. Fukumoto, and S. Hayashi, Proceedings of the International Symposium on High-Temperature Corrosion and Protection, Hokkaido, Japan, 2000, pp 351.

6. Y. Wu, G. M. Song, Y. M. Wang, and T. Narita, Oxidation of Metals 74, 287 (2010).

7. T. Narita, K. Z. Thosin, L. Fengqun, S. Hayashi, H. Murakami, B. Gleeson, and D. Young, Materials and Corrosion 56, 923 (2005).

8. M. H. Li, X. F. Sun, J. G. Li, Z. Y. Zhang, T. Jin, H. R. Guan, and Z. Q. Hu, Oxidation of Metals 59, 591 (2003).

9. M. H. Li, X. F. Sun, T. Jin, H. R. Guan, and Z. Q. Hu, Oxidation of Metals 60, 195 (2003).

10. P. Kuppusami and H. Murakami, Surface and Coatings Technology 186, 377 (2004).

11. N. Czech, F. Schmitz, and W. Stamm, Surface and Coatings Technology 68/69, 17 (1994).

12. M. Reid, M. J. Pomeroy, and J. S. Robinson, Journal of Materials Processing Technology 153-154, 660 (2004).

13. C. M. F. Rae, M. S. Hook, and R. C. Reed, Materials Science and Engineering A 396, 231 (2005).

14. T. Izumi, T. Nishimoto, and T. Narita, Intermetallics 13, 727 (2005).

15. Y. Wu and T. Narita, Materials and Corrosion 60, 781 (2009).

16. C. T. Liu, X. F. Sun, H. R. Guan, and Z. Q. Hu, Surface and Coatings Technology 194, 111 (2005).

17. W. Beele, N. Czech, W. J. Quadakkers, and W. Stamm, Surface and Coatings Technology 94-95, 41 (1997).

18. Y. H. Zhang, D. M. Knowles, and P. J. Withers, Surface and Coatings Technology 107, 76 (1998).

19. C. T. Liu, X. F. Sun, H. R. Guan, and Z. Q. Hu, Surface and Coatings Technology 197, 39 (2005).

20. J. Angenete and K. Stiller, Materials Science and Engineering A 316, 182 (2001).

21. J. Angenete, K. Stiller, and V. Langer, Oxidation of Metals 60, 47 (2003).

22. J. Angenete and K. Stiller, Oxidation of Metals 60, 83 (2003).

23. Z. H. Xu, L. M. He, R. Mu, X. H. Zhong, and X. Q. Cao, Vacuum 82, 1251 (2008).

24. F. Q. Lang and T. Narita, Intermetallics 15, 599 (2007).

25. C. Z. Xu, S. M. Jiang, Z. B. Bao, J. Gong, and C. Sun, Corrosion Science 51, 1467 (2009).

26. J. A. Haynes, Y. Zhang, K. M. Cooley, L. Walker, K. S. Reeves, and B. A. Pint, Surface and Coatings Technology 188-189, 153 (2004).

27. Z. H. Xu, R. D. Mu, L. M. He, and X. Q. Cao, Journal of Alloys and Compounds 466, 471 (2008).

28. J. Müller and D. Neuschütz, Vacuum 71, 247 (2003).

29. J. E. Schilbe, Surface and Coatings Technology 133-134, 35 (2000).

30. H. F. Li, S. F. Tao, Z. H. Zhou, L. D. Sun, A. Hesnawi, and S. K. Gong, Surface and Coatings Technology 201, 6589 (2007).

31. Y. Q. Wang and G. Sayre, Surface and Coatings Technology 203, 2186 (2009).

32. K. Tukagoshi, Y. Kawata, A. Muyama, J. Masada, S. Uchida, I. Okada, and E. Ito, Mitsubishi Heavy Industries Technical Review 42, 3 (2005).

33. C. S. Giggins and F. S. Pettit, Journal of the Electrochemical Society 118, 1782 (1971).

34. F. S. Pettit, Transactions of the Metallurgical Society of AIME 239, 1296 (1967).

35. F. Wu, H. Murakami, and A. Suzuki, Surface and Coatings Technology 168, 62 (2003). 